\title{
THE PIENINY KLIPPEN BELT: ITS TECTONIC STRUCTURE AND EVOLUTION
}

\section{G. Leonov}

Geological Institute of RAS, Moscow, Russia

\begin{abstract}
Many mobile belts contain narrow (a few kilometres wide) and elongated (several hundreds and thousands kilometres long) zones characterized by complicated tectonic interiors and intensive rock metamorphism. Such zones are important components of the crustal structure; they determine the internal divisibility of the crust and act as accommodation areas or buffers between fragments of the crust which differ in origin and have specific evolution features. The article describes the paleo-evolution and characteristics of the Pieniny klippen belt, a major tectonic structure of the Carpathians and one of the largest linear tectonic zones in the Alpine-Himalayan folded belt.
\end{abstract}

Key words: tectonics, deformation, tectonic flow, folded belt, flower-type structure, Pieniny klippen belt.

Recommended by K.Zh. Seminsky

Citation: Leonov M.G. 2014. The Pieniny klippen belt: its tectonic structure and evolution. Geodynamics \& Tectonophysics 5 (3), 703-715. doi:10.5800/GT-2014-5-3-0150.

\section{ПЬЕНИНСКИЙ УТЕСОВЫЙ ПОЯС: ТЕКТОНИЧЕСКАЯ СТРУКТУРА И ЭВОЛЮЦИЯ}

\author{
М. Г. Леонов \\ Геологический институт РАН, Москва, Россия
}

Аннотация: В пределах многих подвижных поясов известны узкие (первые километры) и протяженные (до нескольких сотен и тысяч километров) зоны с очень сложной внутренней тектонической структурой и интенсивной вещественной переработкой горных масс. Они играют существенную роль в структуре земной коры, определяя ее внутреннюю делимость и являясь зонами раздела (аккомодации, буфера) между разными по природе и особенностям эволюции фрагментами земной коры. В статье приведены описание и характеристика особенностей палеоэволюции Пьенинского утесового пояса, который является одним из главных структурно-тектонических элементов Карпатского горного сооружения и одной из крупнейших линейных структурно-тектонических зон Альпийско-Гималайского покровно-складчатого пояса.

Ключевые слова: тектоника, деформация, тектоническое течение, складчатый пояс, структура «цветка», Пьенинский утесовый пояс. 


\section{1. ВВЕДЕНИЕ}

В ряду пронизывающих земную кору крупных линейных структур (глубинных разломов, линеаментов, трансформных разломов и пр.) выделяются узкие (первые километры) и протяженные (до нескольких сотен и тысяч километров) зоны с очень сложной внутренней тектонической структурой и интенсивной вещественной переработкой горных масс [Azhgirey, 1960; Konygin et al., 1988; Leonov, 2012; Morozov, 2002; Stefanov, 2002; Stefanov, Bakeev, 2013; Chikov, 2011; Alvarez, Maurin, 1991; McCourt, Wilson, 1992; и др.]. В ряде случаев такие структуры из-за морфологического сходства с соответствующими растениями называют «структурами цветка» (flower structures) или «структурами пальмового дерева» (palm-tree structure) [Morozov, 2002; Stefanov, 2002; Sanderson, Marchini, 1984; Sylvester, 1988]. Подобные структуры описаны как «зоны смятия» или «зоны концентрации деформаций», «линеаментные деформационно-метаморфические зоны», «зоны концентрации сдвиговых деформаций», «безофиолитовые коллизионные швы», «глубинные разломы». В настоящее время предложено использовать термин, введенный Г.Д. Ажгиреем [Azhgirey, 1960] и удачно использованный Л.М. Расцветаевым [Rastsvetaev, 1973], и именовать эти зоны «зонами концентрированной деформации» [Leonov, 2012], делая акцент на обязательном их признаке, а именно повышенной в сравнении с фоновой структурно-вещественной переработке горных масс. Немаловажно также и то, что термин более или менее адекватен англоязычному «high-strain shear zones». Общие вопросы геологии и геодинамики зон концентрированной деформации рассмотрены во многих работах, данные которых суммированы и обобщены в работе автора [Leonov, 2012]. Здесь же речь пойдет о зоне Пьенинских утесов одного из крупнейших линейных структурно-тектонических элементов Карпатского горного сооружения, входящего в состав Альпийской складчато-покровной области и являющегося структурным разделом между зонами Внешних и Внутренних Карпат. В статье приведены описание структуры и характеристика особенностей палеоэволюции этого структурного шва.

\section{2. ПЬЕНИНСКИЙ УТЕСОВЫЙ ПОЯС}

\section{1. ПОЛОЖЕНИЕ В СТРУКТУРЕ КАРПАТ, СТРОЕНИЕ}

Пояс Пьенинских утесов является одним из главных тектонических элементов Карпатского горного сооружения. Образуя выгнутую к северу дугу, он тянется в общекарпатском направлении почти на 900 км от окрестностей Вены на западе до Мармарошского массива на востоке, сохраняя на всем протяжении очень незначительную (2-5 км, на отдельных пересе- чениях до 20 км) ширину (рис. 1). Сведения по геологии зоны Пьенинских утесов содержатся в многочисленных публикациях [Andrusov, 1967; Birkenmajer, 1956, 1963a, 1963b, 1965, 1970; Bogdanov et al., 1958; Burtman, 1984; Vyalov, 1956; Kruglov, 1971; Ksenshkevich et al., 1968; Kulchitsky, 1967; Leonov, 1978; Leshko, 1963; Aleksandrovicz, 1966; Andrusov, 1953, 1974; Birkenmajer, Lefeld, 1969; Burtman, 1986; Kotański, 1963; Ksiażkiewicz, 1963, 1972; Scheibner, 1969; Sikora, 1971; Tołwińsky, 1956], данные которых будут использованы в этой работе. Литературные материалы дополнены данными личных наблюдений, которые автору посчастливилось сделать в Польских Карпатах во время работы с некоторыми из перечисленных выше польских геологов. Я искренне признателен А. Токарскому, К. Биркенмайеру, М. Джулинскому, Е. Лефельду, Р. Маршалко за помощь в проведении полевых работ, деловое обсуждение проблем карпатской геологии и дружеское участие.

Зона Пьенинских утесов сложена рыхлыми песчано-глинистыми и мергелистыми отложениями верхнего мела - палеогена, среди которых хаотично расположены хорошо выделяющиеся в рельефе, тектонически разобщенные фрагменты (чешуи, глыбы, блоки) плотных кремнисто-карбонатных пород юрского и нижнемелового возраста. Рыхлые отложения образуют, по выражению карпатских геологов, «осадочную оболочку» утесов, массивы плотных пород формируют собственно «утесы» (клипы), резко доминирующие в рельефе (рис. 2). Утесы сложены породами нескольких «утесовых серий», имеющих различные состав и строение (об этом - ниже).

Породы осадочной оболочки смяты в складки, сжатые до изоклинальных, чаще всего с субвертикально- и крутонаклонными осевыми плоскостями, иногда неправильной формы и имеющие хаотический облик. Основная масса пластичных глинисто-мергельных пород зачастую рассланцована и покрыта на плоскостях сланцеватости многочисленными зеркалами скольжения. Пласты компетентных пород (песчаников, алевролитов, кремней) разлинзованы, будинированы, закручены.

Утесы образуют несколько рядов соприкасающихся, надвинутых друг на друга и перекрывающих одни другие тектонических чешуй и покровов. Наблюдается надвигание пород, сложенных породами одной серии, на отложения иных серий. При тектоническом перекрытии отдельные серии обнажаются только в тектонических окнах. Покровные пластины сами зачастую смяты в складки. Утесы ограничены, как правило, поверхностями разрывов с зонами милонитизации и брекчирования и представляют собой бескорневые глыбы, блоки и пластины, размер которых колеблется в широких пределах - от первых метров до многих километров в длину. Первоначально единые пластины часто будинированы и разорваны, при этом будины или находятся на одной линии или смещены одна от- 


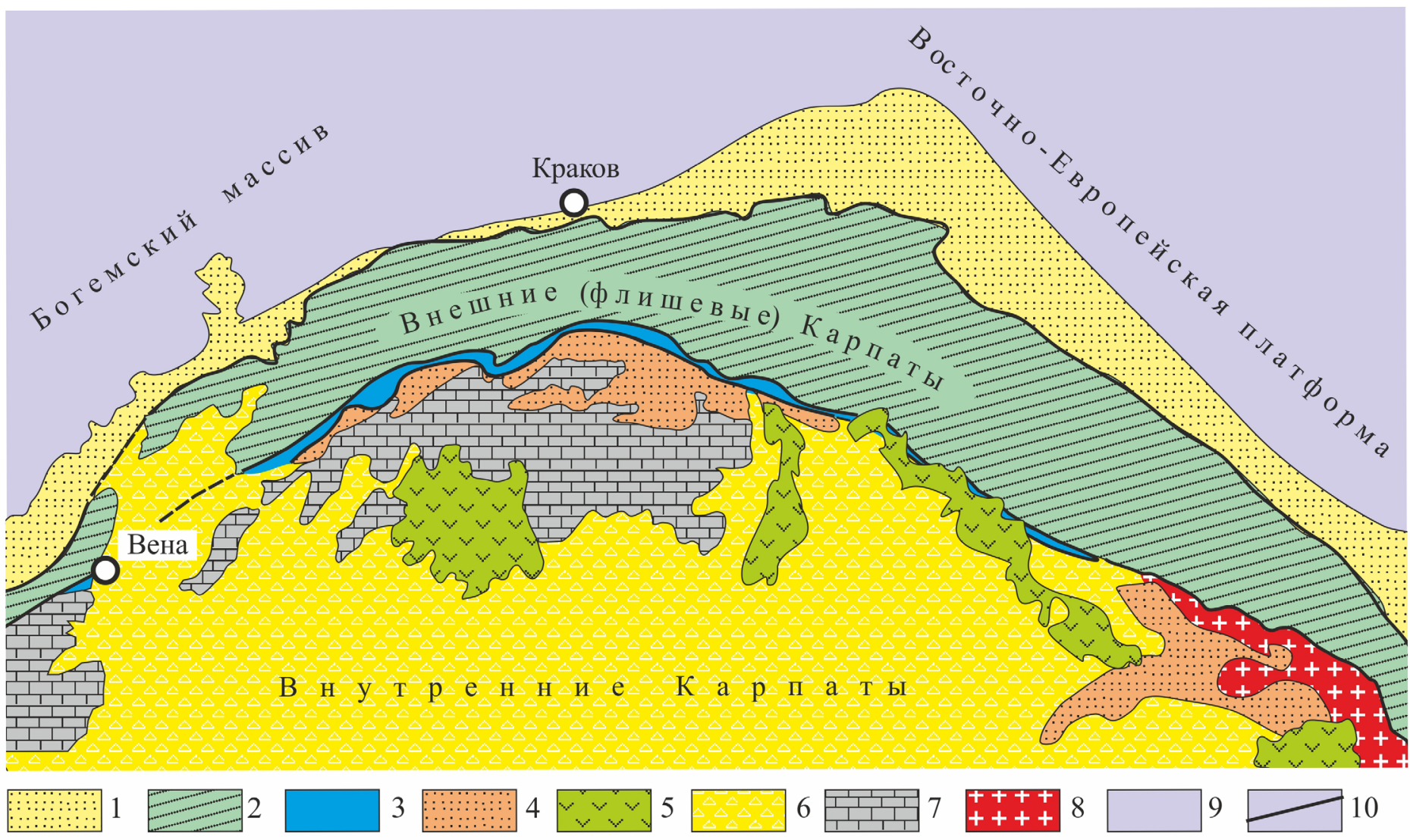

Рис. 1. Схема расположения основных тектонических элементов северной части Карпатского горного сооружения.

1-2 - Внешние Карпаты: 1 - Предкарпатский краевой прогиб, 2 - флишевые Карпаты; 3 - Пьенинский утесовый пояс; 4 - Мармарошский кристаллический массив; 5-8 - Внутренние Карпаты: 5 - Подгальский флиш, 6 - неогеновые вулканиты, 7 - неоген-четвертичные молассы внутренних впадин, 8 - допалеогеновое основание; 9 - Восточно-Европейская платформа и область распространения европейских герцинид; 10 - главные разломы, разграничивающие структурно-формационные элементы Карпатского орогена.

Fig. 1. Locations of main tectonic elements of the Northern Carpathians.

1-2 - Peripheral Carpathians: 1 - Pre-Carpathian marginal trough, 2 - flysch Carpathians; 3 - Pieniny klippen belt; 4 - Marmarosh crystalline massif; 5-8 - Inner Carpathians: 5 - Podgalsky flysch, 6 - Neogenic volcanite, 7 - Neogenic - Quaternary molasses of inner basins, 8 - PrePaleogenic basement; 9 - East European platform and area of European Hercynides; 10 - main faults bordering structural and formational elements of the Carpathian orogen.

носительно других по поперечным разрывам.

Структура осложняется дифференциальным проскальзыванием блоков пород разного состава, компетенции и возраста относительно друг друга. Отдельные пластины и блоки как бы плавают в толще более пластичных пород (рис. 3).

Все породы в пределах пояса за редким исключением залегают круто, часто вертикально. При приближении к границам пояса наблюдается разваливание в стороны от центра и в целом наблюдается веерообразное строение пояса. При этом длинные оси «утесов», особенно имеющих форму пластин, ориентированы в большинстве случаев вдоль продольной оси пояса. В этом же направлении ориентированы и длинные оси будин, сложенных как породами «утесовых серий», так и компетентными разностями отложений вмещающей пластичной массы.
Внутренняя структура свидетельствует об интенсивном тектоническом скучивании осадочных образований, а также о хрупко-пластическом продольном к оси пояса тектоническом течении. Следовательно, в совокупности она отражает условия транспрессии.

\section{2. ПОСЛЕДОВАТЕЛЬНОСТЬ НАПЛАСТОВАНИЯ, СТРУКТУРНО- ФОРМАЦИОННАЯ ЗОНАЛЬНОСТЬ}

На основании особенностей строения разрезов отложений, слагающих утесы, различают несколько «утесовых» серий, каждая из которых соответствует определенной области бассейна седиментации. Четко можно выделить три группы серий, существенно различающихся по составу и строению слагающих их отложений. Некоторые серии прослежены в виде фрагментов практически на всем протяжении пояса. 

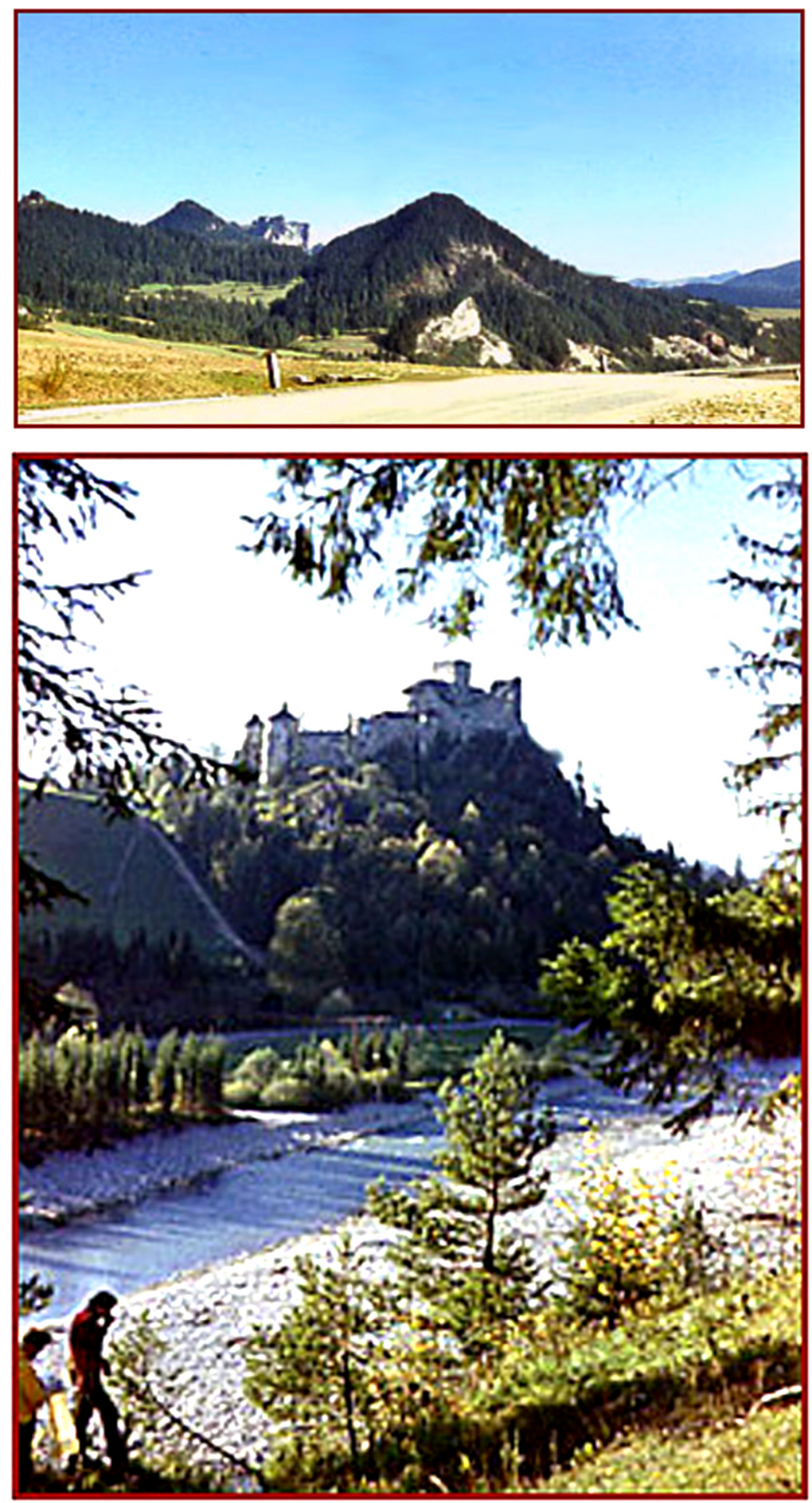

Рис. 2. Рельеф зоны Пьенинских утесов. На вершинах многих утесов расположены старинные замки и крепости.

Fig. 2. Topography of the Pieniny cliffs. Ancient castles and fortresses are located on tops of many cliffs.

На территории Польши - будем оперировать данными именно по этому сегменту Пьенинского пояса, поскольку они получены по личным наблюдениям среди Пьенинских утесов выделены (ссылки см. выше) следующие «утесовые серии»: чорштынская, чертезицкая, недзицкая, бранисская, пьенинская и халиговецкая (последняя на территории Словакии) (рис. 4, 5). Однако различия между некоторыми сериями столь незна- чительны, что многие геологи выделяют три группы серий: чорштынскую, переходную, собственно пьенинскую группу серий и Халиговецкую (клапскую серию). Утесы чорштынской серии преобладают в северных частях пояса, утесы пьенинской - в центральных и южных. Халиговецкая серия известна только в утесах, расположенных вдоль самого южного ограничения пояса. Южнее области развития трех перечис- 


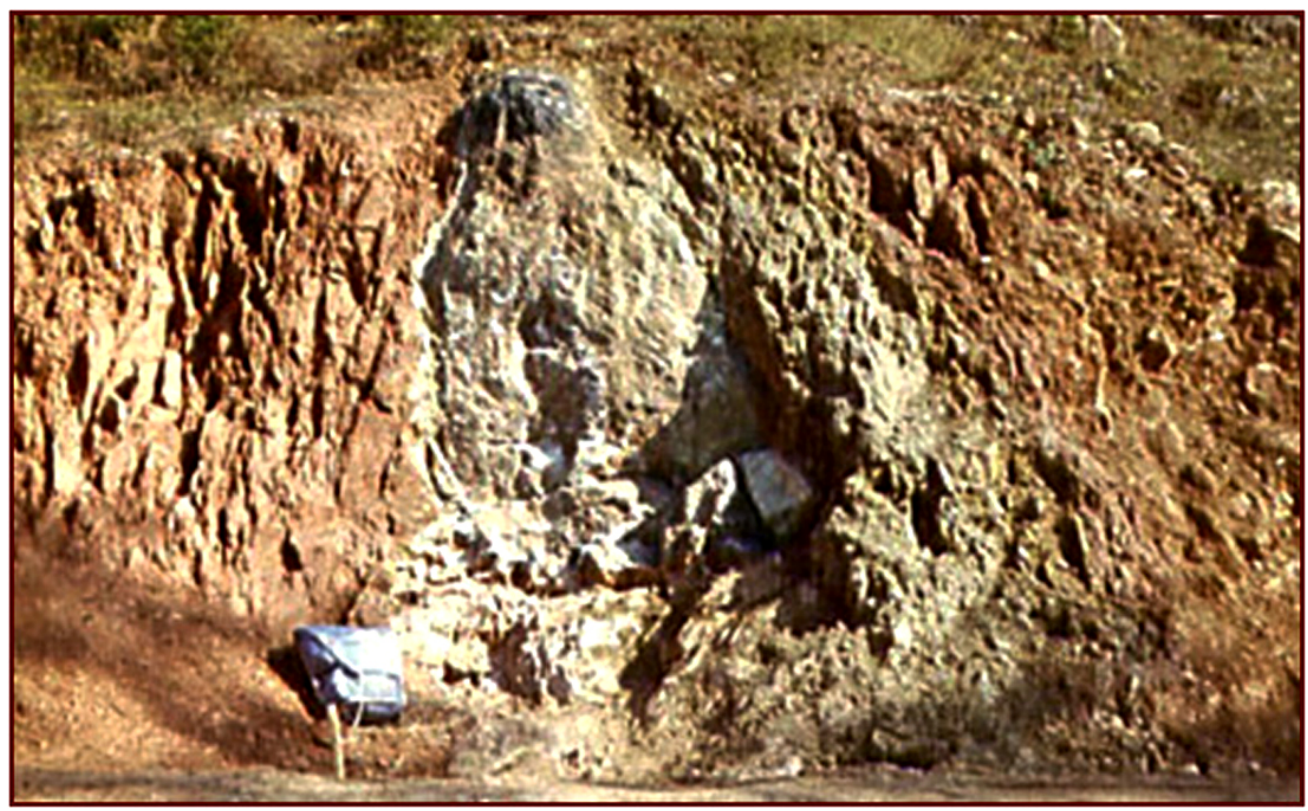

Рис. 3. Изолированная глыба известняков средней юры среди рассланцованных мергелей верхнего мела.

Fig. 3. An isolated slab of the Middle Jurassic limestone among schistose marlstones of the Upper Cretaceous.

ленных серий, на территории Словакии, известны отложения манинской серии, которые имеют явные признаки принадлежности к области Внутренних Карпат (верховая серия Высоких Татр).

На территории Польши в пределах зоны наиболее древние слои утесовых серий представлены средним лейасом, а на территории Словакии известны и более древние образования триаса - нижнего лейаса. Для чорштынской серии - это ладинские (?) доломиты и ладинско-карнийские известняки с кораллами. Разрез пьенинской серии начинается верхним триасом в фации гипсоносного кейпера, выше залегает рэт в швабской фации и нижний лейас - в грестенской (известняки и темные сланцы). В халиговецкой серии средний триас представлен доломитовыми известняками, кепер - доломитами.

Наиболее полные разрезы утесовых серий можно проследить с верхнего лейаса. В это время начинают проявляться существенные различия в составе отложений, формирующих утесы (см. рис. 4, 5).

Разрез чорштынской группы серий (юра - неоком):

1. «Опалинусовые» слои (домер - средний аален): серые и голубовато-серые мергели и мергелистые известняки (мощность неизвестна).

2. «Мурчисониевые» слои (верхний аален - средний байос): глинистые сланцы, черные, голубые и зеленоватые мергелистые глины с конкрециями сферосидеритов (10-30 м).

3. «Белый криноидный известняк» (верхняя часть среднего байоса - нижняя часть верхнего байоса): неслоистые средне- и крупнокристаллические известняки с зернами кварца и обломками триасовых известня- ков и доломитов, с фауной брахиопод (100-150 м).

4. «Красный криноидный известняк» (верхний байос - бат): мелко- и среднекристаллические известняки с зернами кварца и обломками триасовых известняков и доломитов, с фауной брахиопод (2-18 м).

Верхняя поверхность криноидных известняков покрыта гематитовыми и лимонитовыми корками хардграунда, образование которых связано с замедлением темпов осадконакопления и размывом пород в результате восходящих движений на границе батского и келловейского веков. В ряде мест красные известняки полностью уничтожены эрозией.

5. «Чорштынский комковатый известняк» (келловей - кимеридж): темно- и светло-красные, неясно-слоистые, комковатые известняки с брекчиевидной структурой: желваки сцементированы карбонатно-гематитовым цементом; местами наблюдаются массовые скопления аммонитов (6-15 м).

Чорштынский известняк залегает или на «красном», или непосредственно на «белом криноидном известняке»; в последнем случае он подстилается осадочными брекчиями из обломков пород нижележащего слоя. Комковатые известняки отлагались не повсеместно хиатус существовал, вероятно, не только в келловейское, но и в оксфордское время.

6. «Дурштынский известняк» (титон): слоистые и неслоистые красные кальпионелловые и криноидные известняки, ракушечники, детритовые известняки (25 M).

7. «Лысанский известняк» (верхний титон - берриас): брахиоподовые, криноидно-брахиоподовые, детритовые красные известяки (10 м). 
M.G. Leonov: The Pieniny klippen belt...

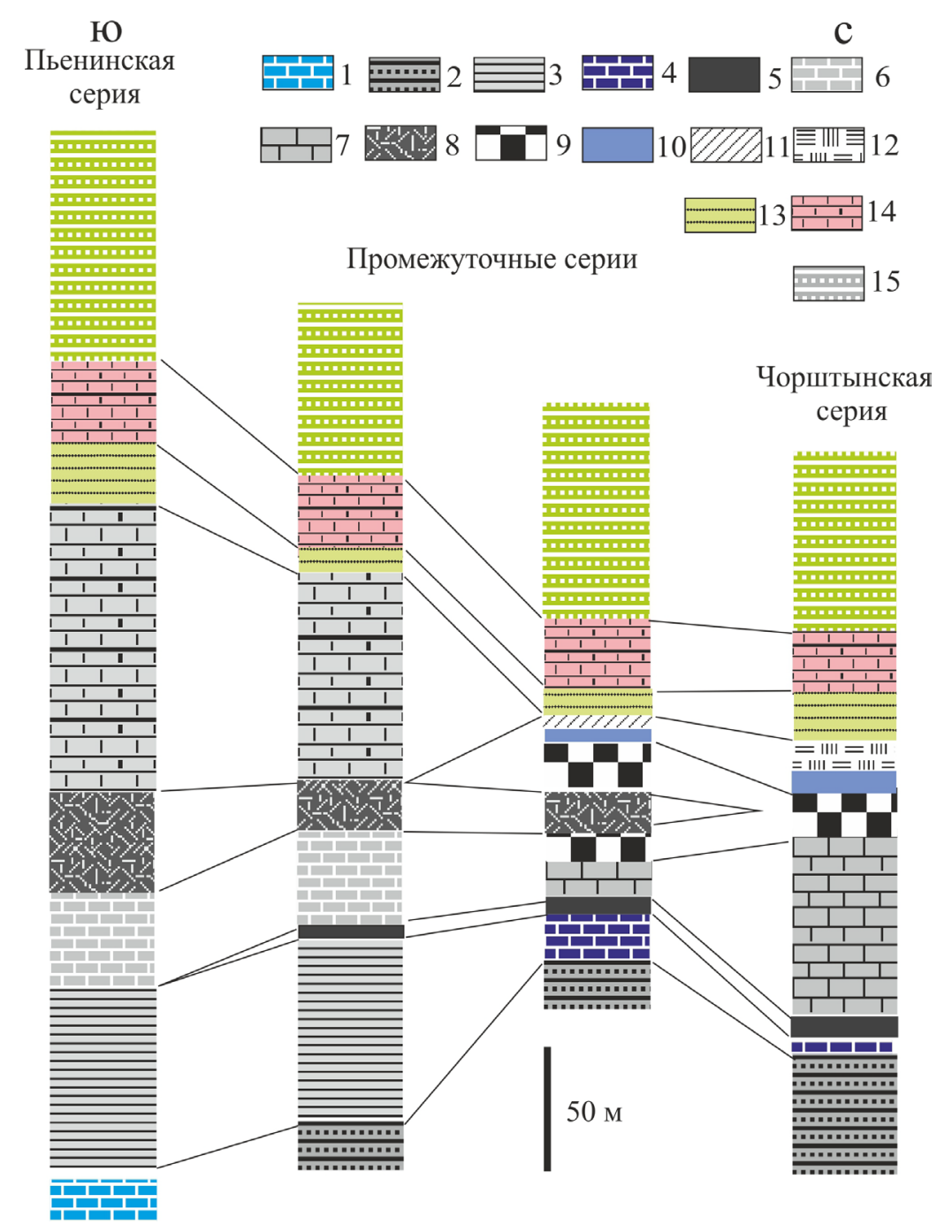

Рис. 4. Стратиграфические разрезы «утесовых» серий северной и центральной частей пьенинского бассейна (по [Birkenmajer, 1963b; Ksenshkevich et al., 1968].

1 - лейас: известняки пятнистые; 2-5 - аален: 2 - флиш, 3 - посидониевые слои, сланцы, 4 - известняки и мергели, 5 - сланцы со сферосидеритами; 6-7 - доггер: 6 - известняки, мергели, 7 - криноидные известняки; 8-9 - мальм: 8 - радиоляриты, 9 - желваковые известняки; 10-12 - титон-неоком: 10 - известняки с кальпионеллами, 11 - известняки с прослоями кремней и с аптихами, 12 - криноидные известняки; 13 - альб: песчанистые мергели; 14 - сеноман-турон-коньяк: зеленые и красные мергели; 15 - коньяк-сантон: флиш.

Fig. 4. Stratigraphic cross-sections of 'cliff' series in the northern and central parts of the Pieniny basic according to [Birkenmajer, 1963b; Ksenshkevich et al., 1968].

1 - Liassic: mottled limestone; 2-5 - Aalenian: 2 - flysch, 3 - Posidonian beds, shale, 4 - limestone and marlstone, 5 - shale with spherosiderite; 6-7 - Dogger: 6 - limestone, marlstone, 7 - crinoidal limestone; 8-9 - Malm: 8 - radiolarite, 9 - nodular limestone; 10-12 - Tithonian-Neocomian: 10 - limestone with calpionellae, 11 - limestone with silicium interbeds and aptiches, 12 - crinoidal limestone; 13 - Albian: sandy marlstone; 14 - Senomanian-Turonian-Coniacian: green marlstone and red marlstone; 15 - Coniacian-Santonian: flysch.

8. «Списский известняк» (берриас - валанжин): криноидные, темно-красные слоистые и сланцеватые известяки с аптихами (40-60 м).

Выделенные типы известняков титона - неокома распространены не повсеместно. Отмечаются перерывы в осадконакоплении, которые на разных участках охватывают различные временные интервалы титона неокома или весь неоком.

Отложения юры - неокома образовались, хотя и в открытом морском бассейне, но на относительном мелководье, в пределах подводных отмелей и их склонов. Об этом свидетельствуют: фациальный состав отложений (ракушняки, детритовые, обломочные и комковатые $^{1}$ известняки), наличие большого количества горизонтов хардграунда и седиментационных перерывов, перемыв и переотложение более древних горизон-

\footnotetext{
${ }^{1}$ Розовые комковатые известняки относятся к фации «аммонитико россо», известные в пределах Альпид, где их распространение приурочено к палеоструктурам типа подводных отмелей и их склонов.
} 
Северный борт Переходная Чорштынская серия область
Центральный бассейн Пьенинская серия
Переходная область
Южный борт

Халиговецкая серия
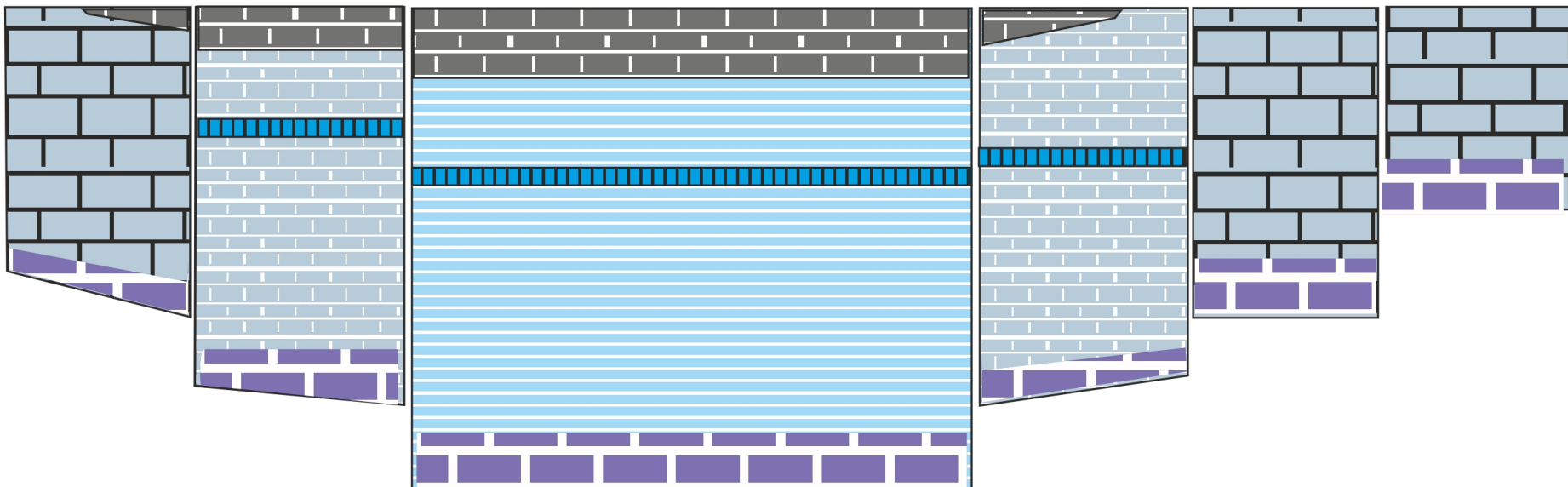

Рис. 5. Обобщенная палинспастическая схема «утесовых» серий Пьенинского пояса (составлена на основе [Kruglov, 1971; Birkenmajer, 1963a; Scheibner, 1969].

1 - карбонатные фации нижнего-среднего триаса; 2 - пелагические мергели альба; 3-6 - верхний триас - альб: 3 - отложения относительно мелководные (детритусовые, брекчиевидные, комковатые известняки, мергели, сланцы, флиш), 4 - отложения переходных фаций (известняки, мергели, карбонатные сланцы, кремни), 5 - относительно глубоководные отложения центрального бассейна (известняки, мергели, кальпионелловые известняки, радиоляриты), 6 - келловей-оксфордские радиоляриты.

Fig. 5. The generalized palinspastic scheme of 'cliff' series of the Pieniny belt. The scheme is based on data from [Kruglov, 1971; Birkenmajer, 1963a; Scheibner, 1969].

1 - carbonate facies of the Low-Middle Triassic; 2 - pelagic marlstones of the Albian; 3-6 - Upper Triassic - Albian: 3 - relatively shallow-water deposits (detritus, breccia, ballstone, marlstone, shale, flysch), 4 - transitional deposits (limestone, marlstone, carbonaceous shale, silicium), 5 relatively deep-water deposits of the central basin (limestone, marlstone, calpionellae limestone, radiolarite), 6 - Callovian-Oxonian radiolarite.

тов в более молодые осадки, присутствие мелководной бентосной фауны.

Общая мощность серии оценивается в 250-300 м.

Разрез пьенинской серии (юра - неоком):

Отложения этой серии слагают утесы, расположенные, как правило, южнее чорштынских или тектонически их перекрывают. На территории Польши наиболее низкие горизонты пьенинской серии представлены отложениями плинсбаха: кремнистыми известняками и мергелями. Выше залегают:

1. «Посидониевые слои» (домер - аален - байос?): серые и черные мергелистые сланцы и сланцеватые известняки с бедной аммонитовой фауной (100 м).

2. «Надпосидониевые слои» (байос - бат): грубоили среднеслоистые голубоватые или коричневатые пятнистые мергели и мергелистые известняки, в верхней части окремненные (50 м).

3. «Радиоляриты» (келловей - оксфорд): в нижней части марганцевые радиоляриты красного цвета, тонкослоистые, с пропластками аргиллитов; выше залегают зеленые радиоляриты, кремнистые известняки и мергелистые сланцы. Венчают разрез красные радиоляриты, кремнистые известняки и мергелистые сланцы (суммарная мощность 60-70 м).

4. «Известняки с кремнями (титон - неоком): тол- стослоистые белые и сероватые пелитоморфные известняки с прослойками и линзочками кремней, с большим количеством аптихов и радиолярий; аммонитовая фауна очень бедная (200 м).

Юрско-неокомские осадки пьенинской серии отлагались в открытом глубоководном бассейне с непрерывной седиментацией в условиях некомпенсированного прогибания, на что указывает незначительная мощность отложений, образование пелагических мергелей, известняков и радиоляритов, отсутствие примеси кластического материала и остатков мелководной фауны. Аммониты встречаются крайне редко, но присутствует большое количество аптихов и радиолярий, которые, в отличие от карбонатных раковин, не подвержены растворению на больших глубинах.

Таким образом, для юры - неокома наблюдаются существенные различия в строении разрезов и характере отложений пьенинской и чорштынской серий. Первая сложена мелководными отложениями, вторая глубоководными. Но как уже говорилось, между этими крайними членами утесовых серий выделяется и несколько «промежуточных», которые имеют черты или чорштынской серии, или пьенинской, или и той и другой одновременно. Устанавливается закономерная смена отложений менее глубоководных более глубо- 
ководными при переходе к каждой из более южных серий.

В самой южной из утесовых серий - халиговейской - выше отложений триаса залегают темные криноидные известняки, кварцитовидные песчаники и красные известковистые сланцы лейаса. Средняя юра представлена темными криноидными известняками, ракушняками и черными роговиками. Верхнеюрские отложения включают серые комковатые известняки с прослоями радиоляритов. Титон - неоком сложен кремнистыми известняками. Характерные отложения барремского-аптского ярусов - «ургонские» известняки, представленные битуминозными, органогенно-детритовыми черными известяками, слоистыми близ подошвы и массивными в кровле.

Эта серия, как и чорштынская, сложена отложениями более мелководными, чем пьенинская, и ее отложения являются переходными от собственно пьенинских серий к «верховой серии» Высоких Татр (Внутренние Карпаты), которые представляют собой южное ограничение Пьенинского бассейна. Таким образом, юрско-нижнемеловые отложения Пьенинского утесового пояса обнаруживают зональную дифференциацию, которая позволяет реконструировать обширный морской бассейн с пелагической седиментацией, ограниченный с севера и с юга подводными отмелями (рис. 6).

Начиная с альба осадконакопление во всех частях бассейна становится более однообразным, однако и здесь удается проследить некоторую дифференцированность отложений в зависимости от места, которое они занимали в бассейне седиментации.

Альб - сеноман. В областях, расположенных южнее Пьенинского пояса (манинская и верховая серии Внутренних Карпат), начинается отложение мергелистых осадков, а позже флишевых с прослоями конгломератов. В южной и центральных частях Пьенинского бассейна образуются глобигерино-радиоляриевые мергели с роговиками.

Ранний - средний сеноман. Продолжается седиментация того же типа, что и в альбе, но в наиболее южной полосе (халиговецкая серия) появляется примесь песчаного материала. В чорштынской серии локально образуются зеленые глоботрункановые мергели, но на большей части этой территории осадконакопление отсутствует.

Поздний сеноман. В это время в основном накапливаются пелагические отложения: пестрые глоботрункановые мергели, на юге - мергели с прослоями алевритов и песчаников. В самом конце позднего сеномана в южных и центральных частях бассейна формируются флишеподобные отложения. К северу песчаного материала становится меньше. В верховой серии Татр отложения этого возраста неизвестны.

Турон. В пределах всего бассейна отлагаются красные мергели, которые в южном направлении обогащаются терригенным материалом.
Коньяк - сантон. В начале коньякского времени формируется тот же тип осадков, что и в туроне. Затем происходит резкая дифференциация «утесового» бассейна. В южной и центральной полосах отлагаются песчаники и сланцы сромовецкого флиша, обломочный материал которого поступал с юга. В северной полосе продолжается накопление мергелей без примеси кластического материала.

Кампан. Заканчивается формирование сромовецкого флиша в южной части бассейна, что, возможно, связано с воздыманием этой области. На севере продолжается накопление пелагических красных мергелей.

Маaстрихт. В конце кампана - начале маастрихта происходит смена условий осадконакопления, обусловленная проявлением ларамийской фазы складчатости и покровообразования. В Пьенинском бассейне, кроме самой северной части чорштынской зоны накапливаются флиш, конгломераты и брекчии ярмуцких слоев. К северу от области распространения отложений чорштынской серии, в Магурской зоне, также шло образование ярмутского флиша; при приближении к чорштынскому порогу флиш фациально замещался глыбовыми брекчиями («клифовая» фация) из обломков пород чорштынской и бранисской серий.

Ранний эоцен. После значительного перерыва в осадконакоплении (даний - палеоцен) на уже тектонически деформированные образования пояса с угловым несогласием ложатся песчаники и конгломераты «межутосового флиша» (суловские конгломераты, шавницкие слои). В конгломератах содержатся обломки пород утесового пояса. Более высокие горизонты палеогена с утесовым поясом имеют недостаточно ясные взаимоотношения. На территории Словакии на дислоцированных образованиях Пьенинского пояса с резким угловым несогласием залегают бурдигальские отложения.

\section{3. ПАЛЕОТЕКТОНИЧЕСКАЯ ЭВОЛЮЦИЯ}

Формирование на месте обширного юрско-раннемелового седиментационного бассейна складчато-покровной структуры и оформление Утесового пояса имели длительную многоэтапную историю (рис. 6).

Строение постнеокомских отложений показывает, что пелагическая седиментация с течением времени сменяется терригенной, флишевой. Кластический материал постепенно распространяется к северу, в глубь Пьенинского бассейна и до его северных окраин. Миграция флишевых отложений с юга на север, складчатость и размыв пород более южных зон и трансгрессивное залегание сеномана свидетельствуют о начале замыкания Пьенинского бассейна.

Последующая фаза сжатия с образованием покровов устанавливается в середине сенона. Но главные движения, приведшие к значительному сокращению бассейна и надвиганию южных серий на северные, произошли в ларамийскую фазу между кампаном и 


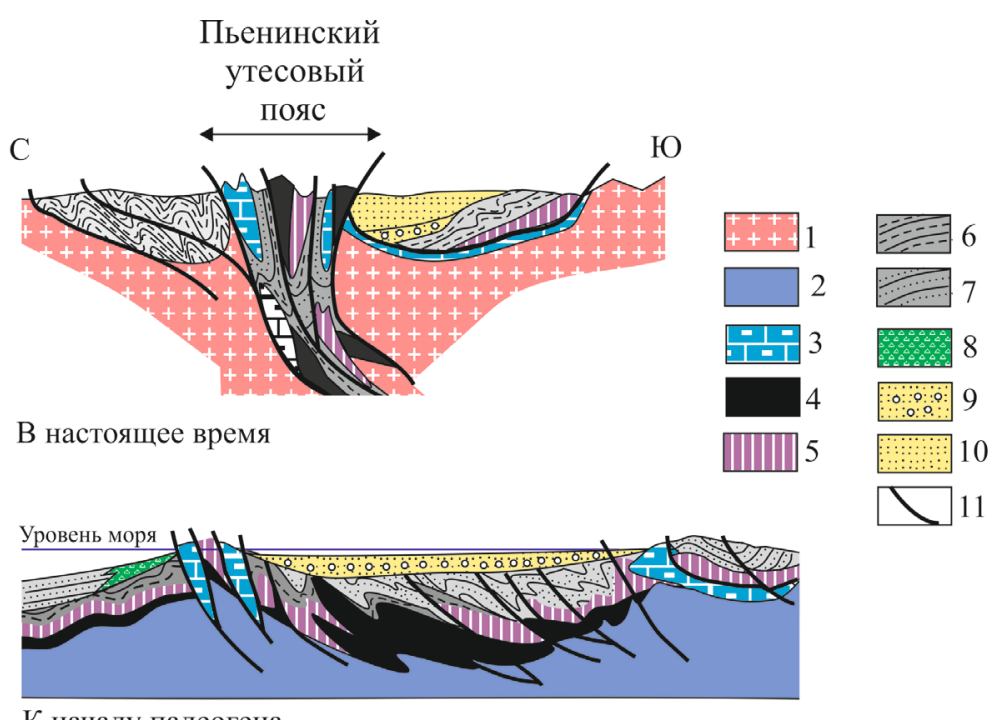

К началу палеогена

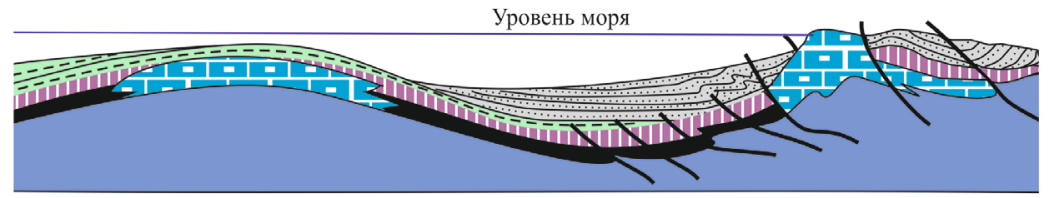

В сантоне

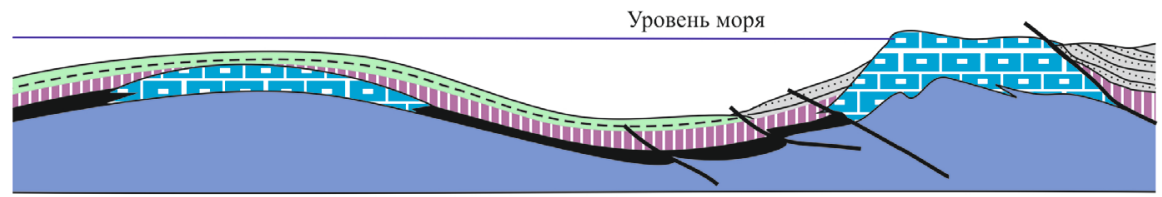

К концу сеномана

$\mathrm{C}$

Уровень моря

Ю

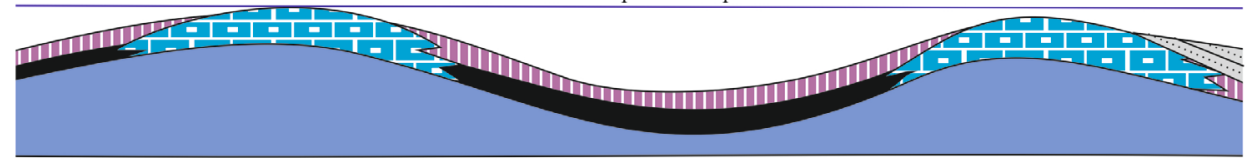

К концу альба

Рис. 6. Схема палеотектонической эволюции Пьенинского утесового пояса (на основе представлений М. Ксеншкевича, Д. Андрусова, К. Биркенмайера, С. Александрова, Е. Шейбнера и др., с использованием материалов личных наблюдений и в интерпретации автора).

1 - Восточно-Европейская платформа и фундамент Внутренних Карпат; 2 - комплексы домезозойского основания Пьенинского бассейна; 3-4 - триас-юрские отложения: 3 - относительно глубоководные: известняки, мергели, радиоляриты, 4 - мелководные: комковатые и криноидные известняки, ракушечники; 5-8 - альбские и более молодые отложения: 5 - глобегерино-радиоляриевые мергели и роговики, 6 - мергели, 7 - терригенные отложения, флиш, 8 - осадочные брекчии; 9 - песчано-глинистые отложения, конгломераты; 10 - палеогеновый флиш; 11 - разломы.

Fig. 6. The paleotectonic evolution of the Pieniny klippen belts. The scheme is based on concepts proposed by M. Ksenshkevich, D. Andrusov, K. Birkenmajer, S. Alexandrov, E. Scheibner and others; personal observations and interpretations by the author are also used.

1 - East Siberian platform and the basement of the Inner Carpathians; 2 - formations of the Pre-Mesozoic basement of the Pieniny basin; 3-4 Triassic-Jurassic deposits: 3 - relatively deep-water deposits of limestone, marlstone and radiolarite, 4 - shallow-water deposits of ballstone and crinoidal limestone, shell stone; 5-8 - Albian and younger deposits: 5 - globigerine-radiolarite marlstone and hornblende, 6 - marlstone, 7 - terrigenic deposits, flysch, 8 - sedimentary breccia; 9 - sandy-clayey deposits, conglomerate; 10 - Paleogenic flysch; 11 - faults.

ранним палеогеном, когда (в кампане - маастрихте) флишевые отложения «выплескиваются» через чорштынский порог в Магурскую зону. Свой современный облик Пьенинский пояс приобрел в результате тектонических движений, которые захватили и фли- шевую зону Внешних Карпат. К бурдигальскому времени в результате общего сжатия уже интенсивно дислоцированные отложения Пьенинского бассейна были сплющены между сближающимися массивами Восточно-Европейской платформы (вместе с залегающим 


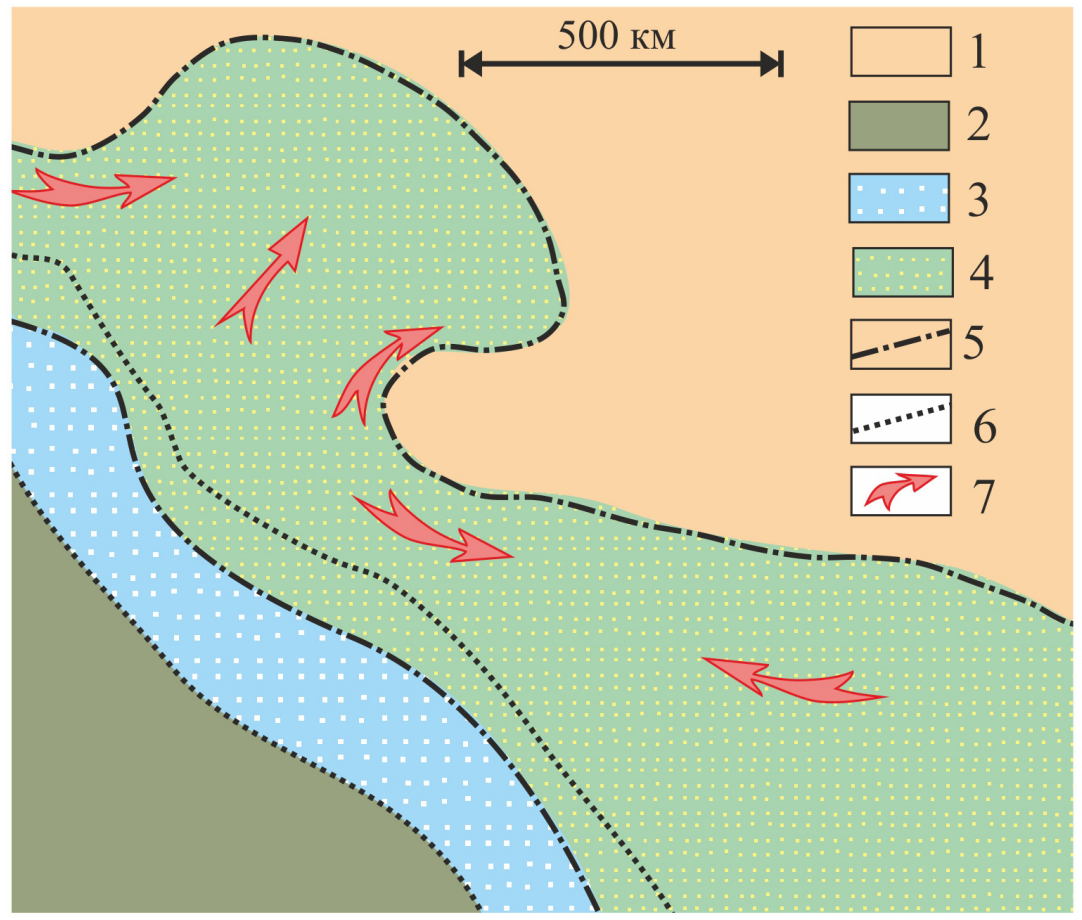

Рис. 7. Схема трансформации положения и формы Карпатской петли в мезозое и кайнозое по палеомагнитным данным (по [Burtman, 1984, 1986, схематизировано].

1 - внеальпийская Европа; 2 - Афро-Аравия; 3 - Альпиды в позднем мелу (по палеомагнитным данным); 4 - Альпиды сегодня; 5 - современные границы Альпид: 6 - предполагаемые границы Альпид в позднем мелу; 7 - направления течения горных масс в процессе деформации пояса.

Fig. 7. Transformation of the position and shape of the Carpathian hinge in the Mesozoic and Cenozoic. The scheme is based on paleomagnetic data from [Burtman, 1984, 1986].

1 - non-alpine Europe; 2 - Afro-Arabia; 3 - Alpides in the Late Cretaceous, according to paleomagnetic data; 4 - current Alpides; 5 - recent boundaries of Alpides; 6 - assumed boundaries of Alpides in the Late Cretaceous; 7 - directions of rock mass flow during deformation of the belt.

на ней тектонически флишем) и Внутренних Карпат и выдавлены в виде гигантской тектонической брекчии («псевдодиапира»). Геофизические данные и палинспастические реконструкции позволяют считать, что отложения Пьенинского бассейна и карпатского флиша частично тектонически перекрыты аллохтонными массивами Внутренних Карпат [Tołwiński, 1956].

Исходя из значительного скучивания гигантских объемов горных масс, тектонического перекрытия одних отложений другими (оно оценивается для отдельных покровов в 10-20 км), протяженности пояса (около 900 км) и существования глубоководного Пьенинского бассейна, ограниченного с севера и с юга поднятиями, можно вслед за карпатскими гологами уверенно допустить, что первичная ширина бассейна была не менее 100-200 км, что подтверждается и данными палеомагнитных исследований [Burtman, 1984].

Таким образом, в результате горизонтального сжатия отложения обширного морского бассейна испытали интенсивное тектоническое скучивание, были превращены в мегабрекчию и выжаты в виде гигантской линейной протрузии в верхние горизонты коры Карпатского горного сооружения. Современная структура пояса сформирована, как можно заключить из наблюдаемых соотношений, следующим образом.

На начальных этапах общее сжатие и начавшееся сокращение пространства в пределах палеоокеана Тетис и его обрамления вызвали деформацию ложа осадочного бассейна и образование складчатых структур в отложениях юры - мела. На границе толщ триаса и нижней юры возник межформационный тектонический срыв, и отложения Пьенинского бассейна деформировались дисгармонично по отношению к подстилающим породам доюрского фундамента. Равным образом структурная дисгармония возникла на уровне раздела относительно компетентных доальбских и относительно пластичных пород мела - палеогена. Кроме межформационной дисгармонии, возникла дисгармония и латеральная, обусловленная различием в составе пород разных утесовых серий и, следовательно, наличием поперечной реологической зональности. В дальнейшем в монолитной по отношению к верхним горизонтам разреза толще известняков и кремней складки трансформировались в надвиги. Система надвигов образовалась и в прибортовых частях поднятий на границе с прогибом. Тектонические пластины и 
чешуи надвигались друг на друга, протыкали оболочку из верхнемеловых мергелей и флиша, вдавливались в пластичные массы. Мергели и флиш вследствие своей податливости испытывали лишь пликативные деформации, сминались в складки, образовывали нагромождения пластичного материала, мощность которого становилась значительно больше первичной.

На поздних этапах деформации, когда произошло общее скучивание и Пьенинский бассейн был редуцирован, выполняющие его отложения трансформировались в систему сжатых и поставленных на голову надвигов и покровов, вдвинутых в сложносмятые пластичные отложения. В это время сдавленные в поперечном направлении породные массы в условиях дефицита пространства испытывают латеральное растекание. Большое значение приобретают процессы будинажа, при которых единые пластины разрываются и растаскиваются по направлению продольной оси пояса, дифференцированно перемещаясь относительно друг друга и вмещающих толщ пластичной оболочки. Заметно проявление диапиризма в пластичных отложениях и тектонического выжимания блоков и пластин компетентных пород в верхние горизонты песчано-мергельной оболочки и по латерали. Включения компетентных пород ведут себя как изюминки в разминаемом тесте. В конечном итоге, как уже говорилось, разнофациальные осадочные образования обширного морского бассейна в результате поперечного скучивания и латерального растекания были трансформированы в гигантскую тектоническую мегабрекчию (меланж с осадочной матрицей) Пьенинского утесового пояса. Нужно отметить, что в данном случае речь идет именно о тектоническом меланже. Осадочное или тектоноосадочное (по терминологии М.Г. Леонова [Leonov, 1981]) происхождение хаотической брекчии исключается, так как в пределах пояса практически отсутствуют олистостромовые комплексы (комплексы гравитационных и тектоногравитационных микститов). Если же говорить о морфоструктурном типе Пьенинского пояса, то он, безусловно, при- надлежит к категории структур «цветка», формирующихся в условиях транспрессии [Morozov, 2002].

\section{3. ЗАКЛЮЧЕНИЕ}

Пьенинский утесовый пояс является одним из элементов Карпатской структурной петли, которая включает в себя горные сооружения Западных, Восточных и Южных Карпат. И естественно, его тектоническая эволюция является отражением и эволюции Карпатского горного сооружения в целом. Достаточно представительный обзор проблемы, сопровождаемый к тому же результатами палеомагнитных исследований, приведен в работах В.С. Буртмана с соавторами [Ваzhenov, Burtman, 1980; Burtman, 1984, 1986], данные которых хорошо коррелируются с изложенным выше материалом.

Палеомагнитные исследования показывают, что Пьенинский бассейн в соответствии с общим положением палеотектонической зональности Альпид в позднем мелу имел простирание ВЮВ - ЗСЗ. В процессе тектонической эволюции горные массы региона, в том числе и Пьенинского бассейна, были перемещены в пространстве, изогнуты и выжаты в виде горизонтальной сигмоиды к северу. Этап сжатия и покровообразования начался на пространстве Внутренних Карпат в середине мела (австрийская фаза). Затем в маастрихте - раннем палеогене ларамийская фаза проявилась в пограничной области Внутренних Карпат и Пьенинского бассейна. Возникновение Карпатской петли, судя по палеомагнитным данным, приходится на интервал палеоген - ранний миоцен, а главные деформации приходятся на конец этого этапа. Изгибание Карпатской дуги стимулирует ее удлинение и, соответственно, вкупе с поперечным сжатием продольное тектоническое течение горных масс. Деформация продолжается и в новейшее время, когда происходит формирование рельефа и окончательное оформление современного облика Пьенинского утесового пояса в виде гигантской «структуры цветка».

\section{4. ЛИTEPATУPA / REFERENCES}

Aleksandrovicz S., 1966. Stratigrafia środkowej i górnej kredy w polskiej cztnsci pieninskego pasa skalkowwigo. Zesz. nauk Acad. Górn.-Hutn, 78.

Alvarez P., Maurin J.-C., 1991. Evolution sédimentaire et tectonique du bassin protérozoïque supérieur de Comba (Congo): Stratigraphie séquentielle du Supergroupe Ouest-Congolien et modèle d'amortissement sur décrochements dans le contexte de la tectogénèse panafricaine. Precambrian Research 50 (1-2), 137-171. http://dx.doi.org/10.1016/03019268(91)90051-B.

Andrusov D., 1953. Coupe géologique à traverse la zone des klippes pienines de vaklle du Vah (Carpathes Slovaques). Geol. sborn. Slov. Akad. Vied 25 (2).

Andrusov D., 1967. Geology of East Carpathians. In: Problems of Geology and Metallogeny of West Carpathians. Bratislava, p. 28-48 (in Russian) [Андрусов Д. Очерк геологии Западных Карпат // Некоторые проблемы геологии и металлогении Западных Карпат. Братислава, 1967. С. 28-48].

Andrusov D., 1974. Etude géologique de la zone des klippes internes des Karpates occidentals. Geol. praze. Sosit 34. Bratislava.

Azhgirey G.D., 1960. About some important regularities of the tectonic structure and movements of the crust. Izvestia AN 
SSSR, Geology Series (8), 3-18 (in Russian) [Ажгирей Г.Д. О некоторых важных закономерностях тектонического строения и движений земной коры // Известия АН СССР. Серия геологическая. 1960. № 8. С. 3-18].

Bazhenov M.L., Burtman V.S., 1980. About the origin of the northern arc of the Carpathians. Doklady AN SSSR 255 (3), $681-$ 685 (in Russian) [Баженов М.Л., Буртман В.С. О природе северной дуги Карпат // Доклады АН СССР. 1980. T. 255. № 3. C. 681-685].

Birkenmajer K., 1956. Sedimentation characteristics of the Yarmut (Maastrichtian) beds of the Pieniny klippen zone (Central Carpathians). Bulletin of the Poland Academy of Sciences, (Section 3) 4 (10) (in Russian) [Биркенмайер К. Седиментационная характеристика ярмутских (маастрихтских) слоев Пьениннской клиповой зоны (Центральные Карпаты) // Бюллетень Польской АН. Отд. 3. 1956. Т. 4. № 10].

Birkenmajer K., 1963a. Zagadnenia sedimentacij utworów fliczowych pieninskiego pasa skałkowigo Połski. Kwart. Geol. 5 , 3-15.

Birkenmajer K., 1963b. Outline of stratigraphy of Mesozoic and Paleogenic deposits of the Pieniny klippen belt in Poland. Bulletin of the Geological Institute, No. 181 (Geological Studies in the Carpathians, V. 10) (in Russian) [Биркенмайер K. Очерк по стратиграфии мезозойских и палеогеновых отложений Пьениннской утесовой гряды в Польше // Бюллетень Геологического института, 181 (Геологические исследования в Карпатах. Т. 10). 1963].

Birkenmajer K., 1965. Przedeoceńskie struktury fałdowe w pieninskim pase skałkowem Połski. Rocz. Pol. Tow. Geol. 35 (3).

Birkenmajer K., 1970. Przedeoceńskie struktury fałdowe w pieninskim pase skałkowem Połski. Stud. Geol. Pol. 31, 17-28.

Birkenmajer K., Lefeld J., 1969. Exotic Urgonian from the Pieniny Klippen Belt of Pjland. Bull. De L'Acad. Pol. des sciences. Ser. Géol., géogr. 85 (1), 138-144.

Bogdanov A.A., Muratov M.V., Khain V.E., 1958. Brief review of tectonic and evolution of West Carpathians. Izvestia vuzov. Geologiya i razvedka (1), 16-32 (in Russian) [Богданов А.А., Муратов М.В., Хаин В.Е. Краткий обзор тектоники и истории развития Западных Карпат // Известия вузов. Геология и разведка. 1958. № 1. С. 16-32].

Burtman V.S., 1984. Kinematics of the Carpathian structural hinge. Geotektonika (3), 17-31 (in Russian) [Буртман В.С. Кинематика Карпатской структурной петли // Геотектоника. 1984. № 3. С. 17-31].

Burtman V.S., 1986. Origin of structural arcs of the Carpathian-Balkan region. Tectonophysics 127 (3), 245-260. http:// dx.doi.org/10.1016/0040-1951(86)90063-6.

Chikov B.M., 2011. Introduction in Physical Bases of Static and Dynamic Geotectonics. GEO Publishing House, Novosibirsk, 300 p. (in Russian) [Чиков Б.М. Введение в физические основы статической и динамической геотектоники. Новосибирск: Академическое издательство «ГЕО», 2011. 300 с.].

Konygin V.G., Leonov M.G., Loshmanov E.V., 1988. Tectonic structure of the Kurganak zone of Southern Tien Shan. Geotektonika (6), 93-106 (in Russian) [Коныгин В.Г., Леонов М.Г., Лошманов Е.В. Тектоническая структура курганакской зоны Южного Тянь-Шаня // Геотектоника. 1988. № 6. С. 93-106].

Kotański Z., 1963. O triasie Skalki Haligoweieckiey i pozycyi paleogeograficzney serii haligowieckiey. Acta geol. Pol. 13 (2).

Kruglov S.S., 1971. The zone of Pieniny cliffs. In: Geological structure and fuels of the Carpathians. Reports of Ukrainian NIGRI. Issue 25. Nedra, Moscow, p. 60-68 (in Russian) [Круглов С.С. Зона Пьенинских утесов // Геологическое строение и горючие ископаемые Карпат. Тр. УкрНИГРИ. Вып. 25. М.: Недра, 1971. С. 60-68].

Ksenshkevich M., Samsonovich Ya., Ryule E., 1968. Outline of Geology of Poland. Nedra, Moscow (in Russian) [Ксеншкевич М., Самсонович Я., Рюле Э. Очерк геологии Польши. М.: Недра, 1968].

Ksiq̨żkiewicz M., 1963. Evolution structural des Carpftes Polonaises. Livre a la memoire du prof. P. Fallo, 2. Paris.

Ksiq̨żkiewicz M., 1972. Karpaty. Budowa geologiczna Polski 4 (3).

Kulchitsky Ya.O., 1967. Main features of the structure of the Marmorosh and Pieniny zones of the Ukrainian Carpathians. In: Issues of Geology of the Carpathians. Publishing House of Lvov State University, Lvov (in Russian) [Кульчицкий Я.О. Основные черты строения Марморошской и Пьенинской зон Украинских Карпат // Вопросы геологии Карпат. Львов: Изд-во Львовского гос. уни-та, 1967].

Leonov M.G., 1978. The paleotectonic evolution of the Pieniny klippen belt (Carpathians). In: Problems of Stratigraphy and Historical Geology. Ed. E.E. Milanovsky. Publishing House of the Moscow State University, Moscow, p. 104-115 (in Russian) [Леонов М.Г. Палеотектоническая эволюция Пьенинского утесового пояса (Карпаты) // Проблемы стратиграфии и исторической геологии / Ред. Е.Е. Милановский. М.: Изд-во МГУ, 1978. С. 104-115].

Leonov M.G., 1981. Olistostromes in the structure of folded areas. Nauka, Moscow, 173 p. (in Russian) [Леонов М.Г. Олистостромы в структуре складчатых областей. М.: Наука, 1981. 173 с.].

Leonov M.G., 2012. Within-plate zones of concentrated deformation: Tectonic structure and evolution. Geotectonics 46 (6), 389-411. http://dx.doi.org/10.1134/S0016852112060052.

Leshko B., 1963. Geology of klippen and flysch zones of East Slovakia. Sovetskaya Geologiya (1) (in Russian) [Лешко Б. Геология клипповой и флишевой зон Восточной Словакии // Советская геология. 1963. № 1].

McCourt S., Wilson J.F., 1992. Late Archaean and Early Proterozoic Tectonics of the Limpopo and Zimbabwe Provinces, Southern Africa. Geol. Dept. and University of West. Austral. 22, 237-245. 
Morozov Yu.A., 2002. Structure-formation function of transpression and transtension. Geotectonics 36 (6), 431-450.

Rastsvetaev L.M., 1973. Some specific features of the Late Alpine structure of orogenic regions in the southern territories of the USSR and recent tectonic stresses. In: Recent tectonics, recent deposits and man. Issue 5. Editors K.K. Markov and N.I. Nikolaev. Publishing House of the Moscow State University, Moscow, p. 57-107 (in Russian) [Расцветаев Л.М. Некоторые особенности позднеальпийской структуры орогенических областей юга СССР и тектонические напряжения новейшего времени // Новейшая тектоника, новейшие отложения и человек. Сб. 5 / Ред. К.K. Марков, Н.И. Николаев. М.: Изд-во Московского ун-та, 1973. С. 57-107].

Sanderson D.J., Marchini W.R.D., 1984. Transpression. Journal of Structural Geology 6 (5), 449-458. http://dx.doi.org/ 10.1016/0191-8141(84)90058-0.

Scheibner E., 1969. Some notes to the Pieniny lineament. Acta geol., geogr. universitatis comeenianae, geol. 18.

Sikora W., 1971. Outline of tectogenesis of the Pieniny klippenzone in Poland in view of new geological data. Rocz. Pol. Tow. Geol. Vjl. 41. Zeszyt 1.

Stefanov Yu.P., 2002. Localization of deformation and destruction in geomaterials. Quantitative modelling. Fizicheskaya Mezomekhanika 5 (5), 107-118 (in Russian) [Стефанов Ю.П. Локализация деформации и разрушение в геоматериалах. Численное моделирование // Физическая мезомеханика. 2002. Т. 5. № 5. С. 107-118].

Stefanov Yu.P., Bakeev R.A., 2013. The structure and stages of formation of a fault zone in the geomedium layer. In: Trigger effects in geosystems. Proceedings of the $2^{\text {nd }}$ All-Russia Workshop. Editors V.V. Adushkin and G.G. Kocharyan. GEOS, Moscow, p. 188-196 (in Russian) [Стефанов Ю.П., Бакеев Р.А. Структура и этапы формирования разломной зоны в слое геосреды // Триггерные эффекты в геосистемах: Материалы II Всероссийского семинара-совещания / Ред. В.В. Адушкин, Г.Г. Кочарян. М.: ГЕОС, 2013. С. 188-196].

Sylvester A.G., 1988. Strike-slip faults. Geological Society of America Bulletin 100 (11), 1666-1703. http://dx.doi.org/ 10.1130/0016-7606(1988)100<1666:SSF>2.3.CO;2.

Tołwińsky K., 1956. Glówne element tektoniczne Karpat z uwzględneniem gorotwory salidow. Acta geol. Pol. 6 (2).

Vyalov O.S., 1956. Deep faults and tectonics of the Carpathians. Geological Reports of the Lvov Geological Society, No. 9 (in Russian) [Вялов O.C. Глубинные разломы и тектоника Карпат // Геологический сборник Львовского геологического общества. 1956. № 9].

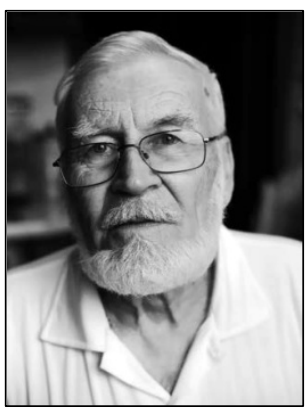

Леонов Михаил Георгиевич, докт. геол.-мин. наук, зав. лабораторией Геологический институт РАН

119017, Москва, Пыжевский пер., 7, Россия

\ e-mail: mgleonov@yandex.ru

Leonov, Mikhail G., Doctor of Geology and Mineralogy, Head of laboratory

Geological Institute of RAS

7 Pyzhevsky lane, Moscow 119017, Russia

\e-mail: mgleonov@yandex.ru 